\title{
Is It Possible to Measure Online Purchasing Intention Trough Technology Acceptance Models?
}

\author{
G.P.H. KANDAMBI ${ }^{1}$ and W.M.J.I. WIJAYANAYAKA ${ }^{2}$ \\ ${ }^{1}$ Rajarata University of Sri Lanka, Department of Business Information Technology, \\ Faculty of Management Studies, Mihintale, Sri Lanka \\ ${ }^{2}$ University of Kelaniya, Department of Industrial Management, Faculty of Science, \\ Dalugama, Sri Lanka
}

Correspondence should be addressed to: G.P.H. KANDAMBI; kandambi@mgt.rjt.ac.lk

Received date: 13 September 2019; Accepted date: 27 March 2020; Published date: 10 September 2020

Academic Editor: Noorshella Che Nawi

Copyright (C) 2020. G.P.H. KANDAMBI and W.M.J.I. WIJAYANAYAKA. Distributed under Creative Commons Attribution 4.0 International CC-BY 4.0

\begin{abstract}
Technology acceptance theories are mainly focused on measuring the acceptability of new technologies and empirically tested through employees in an organization. Currently, these technology acceptance theories are used by researchers to measure the online purchasing intention. However, those theories were directly focused on the technological components, ignoring retailers, customers, media and most other macro components engaged in the online purchasing. Hence, it is compulsory to study the capability of technology acceptance theories to measure the online purchasing intention. The main technology acceptance theories were critically evaluated in their applied contexts, concepts and processes against those of the online purchasing to identify the uniqueness of each model. Finally, it was confirmed that technology acceptance theories were directly used to measure the technology acceptance behavior in an organizational context. However, there were differences in contexts, concepts, processes and theoretical aspects when comparing between the worker in the organizational context and the online consumer in the online purchasing. Hence, those technology acceptance theories cannot be adopted to measure the online purchasing behavior directly. Similarly, Innovation Diffusion Theory (IDT), Unified theory of acceptance and use of technology (UTAUT2) and Theory of Reason Action (TRA) cannot be adopted to measure the online purchasing since they were engaged in new technologies such as online games or emails by individual consumers. Also, a high level of volitional control is needed to apply TRA. Hence, it is mandatory to develop a universal model, which measures the online purchasing with the maximum utilization of previous technology acceptance theoretical aspects.
\end{abstract}

Keyword: Technology Acceptance, UTAUT, Online Purchasing, E-commerce,

Cite this Article as: G.P.H. KANDAMBI and W.M.J.I. WIJAYANAYAKA (2020)," Is It Possible to Measure Online Purchasing Intention Trough Technology Acceptance Models? ", Journal of Internet and e-Business Studies, Vol. 2020 (2020), Article ID 316989, DOI: 10.5171/2020.316989 


\section{Introduction}

Technology Acceptance theories are dominant theories in IS research. Research in this domain has evolved by conceptualizing new factors, which can better explain the phenomena of technology adoption resulting in the growth of many theories. This evolution has been primarily driven by a hastily changing technology scenario and has been headed by new factors, which are from other disciplines.

As part of the analysis, 351 empirical studies were evaluated. Findings show that the Theory of Reasoned Action (Fishbein \& Ajzen, 1975), the Technology Acceptance Model (TAM) (Davis, 1989), the Extensions to TAM (adapted from Wixom \& Todd, 2005), the Theory of Technology Readiness and Acceptance Model, Extended Technology Acceptance Model (TAM2) (Venkatesh \& Davis, 2000), the Motivation Model (Davis et al.1992), the Theory of Planned Behavior (TPB) (Ajzen 1991), Combined TAM and TPB (Taylor \& Todd 1995a), the Model of PC Utilization (Thompson et al., 1991), the Innovation Diffusion Theory (Rogers, 1995), Social Cognitive Theory (Bandura, 1986), the Unified Theory of the Acceptance and Use of Technology (UTAUT) (Venkatesh et al., 2003), and UTAUT2 (Venkatesh et al., 2012) were the theories used primarily by researchers in the field.

\section{Problem Identification}

The time has come for IS researchers to start building their own theories instead of applying theories from other disciplines (Chan et al., 2003). It is, therefore, necessary to consider the IT component when researching the on-line consumer behavior, not blindly deriving theories and models from other disciplines. Therefore, IS researchers should work out behavioral models, declaring what is unique and specific to the context of consumer-based electronic commerce (Chan et al., 2003). Hence, it is required to identify the relevancy of the measurement of technology acceptance theory.

\section{Aim}

In this section, the authors of this paper strive to trace the evolution of various theories and models of technology acceptance over the years. The objective of presenting an overview of these essential theories is to show the gap between the domain based on the technology acceptance theory and the domain of e-commerce.

\section{Methodology}

The main technology acceptance theories were collected, critically evaluated and examined to identify the uniqueness of each model. The applied context, concept and process were evaluated in each model as well.

\section{Review of Technology Acceptance Models}

\section{The Theory of Reasoned Action (TRA)}

Ajzen and Fishbein introduced this theory describing a person's behavioral intention leading to a person's actual behavior in 1967. The attitude towards Behavior, Subjective Norms, Behavioral Intention and Actual Behavior are the main components of this theory. Besides, a person's behavioral intention is determined by his/her attitude towards the behavior and his/her subjective norms (social influence). Hence, the most important factors determining the behavior are Attitude towards Behavior and Subjective Norms.

Subjective norms are determined by two types of beliefs, namely, normative beliefs and salient beliefs. Normative beliefs, which have the highest impact on subjective norms, relate to the individual's perceptions about the possible views of referent groups or individuals on whether or not they should perform the behavior in question. Situations where individuals have a high level of volitional control are necessary to apply TRA (Al-Suqri \& Al-Kharusi, 2015). Schifter \& Ajzen (1985) suggest that the availability of such opportunities and unique resources, such as having the right skills, enough money, or the necessary co- 
operation of others, are some constraints that limit the human behavior.

Limitation: Credit card availability, enough money, Internet and computer devices, ICT knowledge, infrastructure, retailer constraints, and medium characteristics involved in the online purchasing are considered as a limitation.

Table 1: The Theory of Reasoned Action (TRA)

\begin{tabular}{|l|l|}
\hline Variable & Definition \\
\hline $\begin{array}{l}\text { Attitudes } \\
\text { towards } \\
\text { Behavior }\end{array}$ & $\begin{array}{l}\text { An individual's positive or negative feelings about performing the behavior } \\
\text { (Fishbein \&Ajzen, 1975) }\end{array}$ \\
\hline $\begin{array}{l}\text { Subjective } \\
\text { Norms }\end{array}$ & $\begin{array}{l}\text { An individual's perception of whether other people believe it is important for } \\
\text { the individual that the behavior should be performed (Fishbein \& Ajzen, 1975) }\end{array}$ \\
\hline
\end{tabular}

Source: Developed by the Researcher

\section{The Technology Acceptance Model (TAM)}

The TAM (Davis, Bagozzi \& Warshaw, 1989) is an adaptation of TRA, tailored explicitly for determining the computer usage behavior. TAM is less general than TRA, since TAM specifically contributes to determining perceived usefulness (PU) and perceived ease of use (PEU), intention and actual computer usage or computeracceptance behavior (Davis et al., 1989). Hence, the goal of TAM is to provide a general explanation of the determinants of technology acceptance.

TAM study 1 used a sample of 120 users in IBM Canada's Toronto Development Laboratory. Those users were instructed to rate the usefulness and ease of use of two of the systems available there: PROFS electronic mail and the XEDIT file editor. TAM study 2 used a sample of 40 MBA students who used two graphics applications developed by IBM.

Limitation: This was directly developed for the technology acceptance of a computer. The purpose was to develop and validate two constructs (usefulness and ease of use), which affect the computer usage of the user in an organization (Davis, 1989). Further, TAM mainly focuses on users in the context of an organization. This is reflected in the definition of perceived usefulness in relation to the job performance of the user.

\section{Table 2: The Technology Acceptance Model (TAM)}

\begin{tabular}{|l|l|}
\hline Variable & Definition \\
\hline Perceived Usefulness & $\begin{array}{l}\text { Respective user's subjective probability that using a specific } \\
\text { application system will increase his/her job performance (Davis, } \\
1989)\end{array}$ \\
\hline Perceived ease of use & $\begin{array}{l}\text { The degree to which a prospective user expects the target system to } \\
\text { be free from effort (Davis, 1989) }\end{array}$ \\
\hline Attitude towards usage & Adapted from TRA/TPB \\
\hline
\end{tabular}

Source: Developed by the Researcher

\section{Extensions to TAM}

Davis (1989) states the necessity of subjective norms (person's social influence) in the area of future empirical research on TAM. TRA has introduced the social influence that can impact the behavioral intention (Al-Suqri \& Al-Kharusi, 2015). 
Hence, Malhotra and Galletta (1999) attempt to verify the role of social influences. It is necessary to study the social influences that change users' attitudes in the context of new technologies such as collaborative systems and e-commerce systems (Malhotra \& Galletta, 1999).

Hence, TAM is extended to measure the social influence derived from Kelman's processes of social influence (Chan et al., 2003). This is called a psychological attachment which contains the influence of social influence processes on the user's behavioral intentions and attitudes toward using the technology (Chan et al., 2003). The studies that utilize Extensions to TAM use very similar research methods to maintain the continuity of earlier studies that used TAM (Chan et al., 2003).

Limitation: This study empirically tested the problem with 239 potential users in an MS-Exchange application from the U.S. national healthcare organization (Chan et al., 2003).

\section{Table 3: The Extensions to TAM}

\begin{tabular}{|l|l|}
\hline Variable & Definition \\
\hline Perceived Usefulness & Adopted from TAM \\
\hline Perceived Ease of Use & Adopted from TAM \\
\hline $\begin{array}{l}\text { Attitude Towards } \\
\text { Usage }\end{array}$ & Adopted from TRA/TAM \\
\hline $\begin{array}{l}\text { Psychological } \\
\text { Attachment }\end{array}$ & $\begin{array}{l}\text { The degree of commitment of the IS user toward the system used } \\
\text { based on the effect of social influences on his or her behavior } \\
\text { (Malhotra \& Galletta, 1999) }\end{array}$ \\
\hline
\end{tabular}

Source: Developed by the Researcher

\section{Extended Technology Acceptance Model (TAM2)}

This model (Venkatesh \& Davis, 2000) is developed and tested to explain the usage intentions and perceived usefulness based on social influence and cognitive instrumental processes. User acceptance is significantly affected by both the process of social influence (subjective norms, voluntariness and image) and cognitive instrumental (job relevance, output quality, result demonstrability and perceived ease of use) (Venkatesh \& Davis, 2000). A better understanding of the determinants of perceived usefulness would enable researchers to increase the organizational involvements that create high acceptance and usage of new systems.

TAM2 was tested using longitudinal data collected from four organizations $(n=156)$ in four different systems with a voluntary usage and a mandatory usage. Constructs were measured three times at each organization. TAM2 directly focuses only on the acceptance of software applications within an organizational context (Venkatesh \& Davis, 2000).

Table 4: The Extended Technology Acceptance Model (TAM2)

\begin{tabular}{|l|l|}
\hline Variable & Definition \\
\hline Perceived Usefulness & Adopted from TAM \\
\hline Perceived Ease of Use & Adopted from TAM \\
\hline Subjective Norms & Adopted from TRA/TPB \\
\hline Image & $\begin{array}{l}\text { The degree to which the use of an innovation is perceived to } \\
\text { enhance one's status in one's social system. (Venkatesh \& Davis, } \\
2000)\end{array}$ \\
\hline
\end{tabular}

G.P.H. KANDAMBI and W.M.J.I. WIJAYANAYAKA, Journal of Internet and e-Business Studies, DOI: $10.5171 / 2020.316989$ 


\begin{tabular}{|l|l|}
\hline Job Relevance & $\begin{array}{l}\text { An individual's perception regarding the degree to which the } \\
\text { target system applies to his or her job (Venkatesh \& Davis, 2000) }\end{array}$ \\
\hline Output quality & $\begin{array}{l}\text { A measure of how well the system performs certain tasks } \\
\text { (Venkatesh \& Davis, 2000) }\end{array}$ \\
\hline $\begin{array}{l}\text { Result } \\
\text { Demonstrability }\end{array}$ & $\begin{array}{l}\text { The tangibility of the results of using the innovation (Venkatesh } \\
\text { \& Davis, 2000) }\end{array}$ \\
\hline
\end{tabular}

Source: Developed by the Researcher

\section{The Motivational Model}

The motivational theory studies the adoption and use of information technology (Davis, Warshaw \& Bagozzi, 1992). The behavior of an individual is based on extrinsic and intrinsic motivations. The motivational model hypothesizes that computer programs should be both more useful and more enjoyable in order to increase their acceptability among potential users (Davis et al., 1992).
Perceived usefulness, perceived ease of use and subjective norms are determinants of the extrinsic motivation. Within this study, perceived usefulness is an example of extrinsic motivation, whereas enjoyment is an example of intrinsic motivation. Computer playfulness and enjoyment are determinants of intrinsic motivation (Davis et al., 1992). The ultimate objective of the motivational model is to highlight the influences of perceived usefulness and enjoyment on intentions to use computers in the workplace (Davis et al., 1992).

Table 5: The Motivational Model

\begin{tabular}{|c|c|c|}
\hline Variable & Definition & Construct \\
\hline \multirow[t]{3}{*}{$\begin{array}{l}\text { Extrinsic } \\
\text { Motivation }\end{array}$} & \multirow{3}{*}{$\begin{array}{l}\text { Defined as the perception that users want to perform } \\
\text { an activity "because it is perceived to be instrumental } \\
\text { in achieving valued outcomes that are distinct from } \\
\text { the activity itself, such as improved job performance, } \\
\text { pay, or promotions" (Davis et al., 1992), }\end{array}$} & $\begin{array}{l}\text { Perceived } \\
\text { usefulness }\end{array}$ \\
\hline & & $\begin{array}{l}\text { Perceived ease of } \\
\text { use }\end{array}$ \\
\hline & & Subjective norms \\
\hline $\begin{array}{l}\text { Intrinsic } \\
\text { Motivation }\end{array}$ & $\begin{array}{l}\text { The perception that users will want to perform an } \\
\text { activity "for no apparent reinforcement other than the } \\
\text { process of performing the activity per se" (Davis et al., } \\
\text { 1992), }\end{array}$ & $\begin{array}{l}\text { Playfulness } \\
\text { Enjoyment }\end{array}$ \\
\hline
\end{tabular}

Source: Developed by the Researcher

\section{Theory of Planned Behavior (TPB)}

The Theory of Planned Behavior (TPB) was developed to include the extent to which TRA considers the mandatory situation (Ajzen, 1991). Moreover, TPB also assumes that individuals are rational decision makers.

TPB is adopted to understand individuals' acceptance and use of different new technologies (Taylor \& Todd 1995b). TRA forecasts behaviors only in a real voluntary situation and not in a situation where the individual's behavior is mandatory (Ajzen, 1991). Therefore, TPB is a theory premeditated to forecast the human behavior in particular contexts where computer usage is mandatory (Ajzen, 1991). TRA does not account for the external resources and opportunities available to a person, which control his/her behavior, and this is the main limitation of TRA. To overcome this limitation, Ajzen (1991) introduced behavioral controls inserts into TPB. The beliefs on control and the perceived power are the main 
determinants of perceived behavioral control (Ajzen, 1991).

Table 6: The Theory of Planned Behavior

\begin{tabular}{|l|l|}
\hline Variable & Definition \\
\hline Attitude towards Behavior & Adopted from TRA \\
\hline Subjective Norms & Adopted from TRA \\
\hline $\begin{array}{l}\text { Perceived Behavioral } \\
\text { Control }\end{array}$ & $\begin{array}{l}\text { The perceived ease or difficulty of performing the behavior } \\
\text { (Ajzen 1991). }\end{array}$ \\
\hline
\end{tabular}

Source: Developed by the Researcher

\section{Combined TAM and TPB}

Attitudinal, social and control factors have been used by several theorists to explain IT usage (Taylor \& Todd, 1995). However, Taylor and Todd (1995) agree that TAM has been more advanced to explain IT usage than the usage of other systems.

The most important and influential factors that impact the behavior, such as social and control factors, have not been incorporated in TAM (Taylor \& Todd, 1995). Subjective norms and perceived behavioral control are the two main determinants of the behavioral intention in the TPB. To enhance the predictability of the model, subjective norms (SN) and perceived behavioral control (PBC) are added to TAM, and the resultant model is called the combined TAM- TPB (C-TAM-TPB) (Taylor \& Todd, 1995).

Limitations: In the methodology of the study, Taylor and Todd (1995) focus mainly on IT usage in the workplace setting. However, the study mentions that it used a student setting to gather information rather than a workplace setting, and that this was a limitation. The study attempts only to examine IT usage, which is the use of a computer information resource center (Taylor \& Todd, 1995). This implies that the study determines the IT usage of a user in a workplace.

Table 7: Combined TAM and TPB

\begin{tabular}{|l|l|l|}
\hline Variable & Definition & Construct \\
\hline $\begin{array}{l}\text { Attitude Towards } \\
\text { Behavior }\end{array}$ & Adopted from TRA/TPB & \\
\hline Subjective Norms & Adopted from TRA/TPB & \\
\hline $\begin{array}{l}\text { Perceived Behavior } \\
\text { Control }\end{array}$ & Adopted from TRA/TPB & Self-Efficacy \\
\cline { 3 - 3 } & & Recourse to Facilitating Conditions \\
\cline { 3 - 3 } $\begin{array}{l}\text { Perceived } \\
\text { Usefulness }\end{array}$ & Adopted from TAM & \\
\hline $\begin{array}{l}\text { Perceived Ease of } \\
\text { Use }\end{array}$ & Adopted from TAM & \\
\hline
\end{tabular}

Source: Developed by the Researcher

\section{The Model of PC Utilization}

To determine the factors that influence the use of personal computers, Fashion and Azjen (1975)'s Theory of Reasoned Action
(TRA) has been most often used, which is actually insufficient to predict the usage (Thompson, Higgins \& Howell, 1991). TRA, being widely tested in sociological and psychological research, is lacking certain 
aspects (Thompson et al., 1991). Hence, Thompson et al. (1991) tailored and developed a model to be used in IS contexts to predict PC utilization, and this is called the Model of PC Utilization (MPCU).

Limitation: The population of this study was knowledgeable workers (defined as managers or professionals) who voluntarily used a PC in their jobs (Thompson et al., 1991). The study sample was taken from a sizeable multinational manufacturing organization (Thompson et al., 1991). The study excluded individuals who were required to use a $\mathrm{PC}$.

Table 8: The Model of PC Utilization

\begin{tabular}{|l|l|}
\hline Variable & Definition \\
\hline Social Factors & $\begin{array}{l}\text { Individual's internalization of the reference group's subjective culture and } \\
\text { specific interpersonal agreements that the individual has made with } \\
\text { others, in specific social situations (Thompson et al., 1991). }\end{array}$ \\
\hline Complexity & $\begin{array}{l}\text { The degree to which an innovation is perceived as relatively difficult to } \\
\text { understand and use (Thompson et al., 1991). }\end{array}$ \\
\hline Job Fit & $\begin{array}{l}\text { The extent to which an individual believes that using a technology can } \\
\text { enhance the performance of his or her job (Thompson et al., 1991). }\end{array}$ \\
\hline $\begin{array}{l}\text { Long term } \\
\text { Consequence }\end{array}$ & Outcomes that have a pay-off in the future (Thompson et al., 1991). \\
\hline $\begin{array}{l}\text { Affect } \\
\text { Towards Use }\end{array}$ & $\begin{array}{l}\text { Feelings of joy, elation, pleasure, depression, disgust, displeasure, or hate } \\
\text { arising within an individual associated with a particular act (Thompson et } \\
\text { al., 1991). }\end{array}$ \\
\hline $\begin{array}{l}\text { Facilitating } \\
\text { Condition }\end{array}$ & $\begin{array}{l}\text { The provision of support for users of PCs may be one type of facilitating } \\
\text { conditions that can influence the system utilization (Thompson et al., } \\
\text { 1991). }\end{array}$ \\
\hline
\end{tabular}

Source: Developed by the Researcher

\section{The Innovation Diffusion Theory (IDT)}

The Innovation Diffusion Theory of Rogers (1995) has been adopted to study a variety of innovations. Relative advantage, complexity, compatibility, trialability and observability are the main constructs that are used to measure the influence of the adoption and acceptance behavior of the innovation. Rogers (1995) defines diffusion as "the process in which an innovation is communicated through specific channels over time among the members of a social system. As expressed in this definition, innovation, communication channels, time and social systems are the main aspects of the diffusion of innovations. Further, the innovation-decision process model is divided into three categories; the innovation-decision process, the characteristics of innovation and adopter characteristics.
The innovation process is completed in five steps. First, the knowledge occurs when an individual (or another decision-making unit) is exposed to an innovation's existence and gains an understanding of how it functions. Secondly, the persuasion occurs when an individual (or another decisionmaking unit) forms a favorable or unfavorable attitude towards the innovation. Thirdly, a decision takes place when an individual (or another decisionmaking unit) engages in activities that lead to a choice of adopting or rejecting the innovation. Fourthly, the implementation occurs when an individual (or another decision-making unit) puts a new idea into use. Fifthly and finally, a confirmation takes place when an individual seeks a reinforcement of an innovation-decision, which has already been made, but he/she may change this previous decision if exposed to conflicting messages about the innovation. 
Table 9: The Innovation Diffusion Theory (IDT)

\begin{tabular}{|l|l|}
\hline Variable & Definition \\
\hline $\begin{array}{l}\text { Relative } \\
\text { Advantage }\end{array}$ & $\begin{array}{l}\text { The degree to which an innovation is perceived as being better than the idea } \\
\text { it supersedes. Moore and Benbasat (1991) }\end{array}$ \\
\hline Complexity & $\begin{array}{l}\text { The degree to which an innovation is perceived as relatively difficult to } \\
\text { understand and use. Moore and Benbasat (1991) }\end{array}$ \\
\hline Trialability & $\begin{array}{l}\text { The degree with which an innovation may be experimented on a limited basis. } \\
\text { Moore and Benbasat (1991) }\end{array}$ \\
\hline Comservability & $\begin{array}{l}\text { The degree to which the results of an innovation are visible to others. Moore } \\
\text { and Benbasat (1991) }\end{array}$ \\
\hline
\end{tabular}

Source: Developed by the Researcher.

\section{Social Cognitive Theory}

Other technology acceptance theories such as TAM, TPB and IDT consider unidirectional relationships among the main variables. However, environmental factors, personal factors and behaviors from the social cognitive theory suggest bidirectional relationships among the variables (Bandura, 1986).

\section{Table 10: Social Cognitive Theory}

\begin{tabular}{|l|l|}
\hline Variable & Definition \\
\hline $\begin{array}{l}\text { Outcome } \\
\text { expectation- } \\
\text { Performance }\end{array}$ & $\begin{array}{l}\text { The performance-related consequence of the behavior. Specifically, the } \\
\text { performance expectation, dealing with the job-related outcome } \\
\text { (Compeau \& Higgins, 1995). }\end{array}$ \\
\hline $\begin{array}{l}\text { Outcome } \\
\text { expectation- } \\
\text { Personal }\end{array}$ & $\begin{array}{l}\text { The personal consequence of the behavior. Specifically, personal } \\
\text { expectation, dealing with the individual esteem and sense of } \\
\text { accomplishment (Compeau \& Higgins, 1995). }\end{array}$ \\
\hline Self-Efficacy & $\begin{array}{l}\text { The judgment of one's ability to use a technology to accomplish a } \\
\text { particular job or task (Compeau \& Higgins, 1995). }\end{array}$ \\
\hline Affect & An individual's liking of a particular behavior \\
\hline Anxiety & $\begin{array}{l}\text { An individual's anxious or emotional reaction when performing a } \\
\text { behavior }\end{array}$ \\
\hline
\end{tabular}

Source: Developed by the Researcher

The Social Cognitive Theory describes an interrelation between the environment, people and behavior. It discusses how people acquire and maintain their behavioral patterns. The 'environment' refers to the factors that can affect a person's behavior. There are social and physical environments. Social environments include family members, friends and colleagues. The situation is a person's perception of the place, time, physical features and activities (Bandura, 1986).

\section{The Unified Theory of Acceptance and Use of Technology (UTAUT)}

The Unified Theory of Acceptance and Use of Technology (UTAUT) was formulated from a comprehensive empirical evaluation 
of the main technology acceptance theories (Venkatesh et al., 2003). Then, UTAUT was empirically validated and produced a score (adjusted $\mathrm{R}^{2}=70 \%$ ) that provided a robust tool for an organization to plan and adapt to new technologies. The above mentioned theories were critically examined by Venkatesh et al. (2003), using longitudinal data from four organizations.

Four $(n=4)$ main constructs were identified from the five constructs that resulted from the evaluation. Performance expectancy, effort expectancy, social Influence and facilitating conditions were seen to be the main determinants of users' acceptance. The attitude towards using technology, selfefficacy and anxiety were not factored in as constructs, though the theory was generated from a model evaluation. Furthermore, gender, age, voluntariness and experience were identified as moderating variables in UTAUT (Venkatesh et al., 2003). All the labels used for the constructs describe the essence of the content (Venkatesh et al., 2003).

Limitations: Further, UTAUT highlights the importance of contextual analysis in developing strategies for technology implementation within an organization (Venkatesh et al., 2003). Note that this study collects a sample from the employees distributed in four organizations. Also, employees from four industries in different functional areas have contributed to data collection. Finally, Venkatesh et al. (2003) strongly recommend using the UTAUT model to account for powerful influences occurring in an organizational context. UTAUT has distilled the critical factors and contingencies related to the prediction of the behavioral intention to use technology, where that technology is used primarily in organizational contexts (Venkatesh, Thong \& Xu, 2012).

Table 11: The Unified Theory of Acceptance \& Use of Technology (UTAUT)

\begin{tabular}{|c|c|c|}
\hline Variable & Definition & Construct \\
\hline \multirow{5}{*}{$\begin{array}{l}\text { Performance } \\
\text { Expectancy }\end{array}$} & \multirow{5}{*}{$\begin{array}{l}\text { Performance expectancy is defined as the } \\
\text { degree to which an individual believes that } \\
\text { using the system will help him or her attain } \\
\text { gains in the job performance. }\end{array}$} & Perceived Usefulness \\
\hline & & Extrinsic motivation \\
\hline & & Job Fit \\
\hline & & Relative Advantage \\
\hline & & Outcome Expectation \\
\hline \multirow{3}{*}{$\begin{array}{l}\text { Effort } \\
\text { Expectancy }\end{array}$} & \multirow{3}{*}{$\begin{array}{l}\text { Effort expectancy is defined as the degree } \\
\text { of ease associated with the use of the } \\
\text { system }\end{array}$} & Perceived Ease of Use \\
\hline & & Complexity \\
\hline & & Ease of use \\
\hline \multirow{3}{*}{$\begin{array}{l}\text { Social } \\
\text { Influence }\end{array}$} & \multirow{3}{*}{$\begin{array}{l}\text { Social influence is defined as the degree to } \\
\text { which an individual perceives that } \\
\text { significant others believe he or she should } \\
\text { use the new system. }\end{array}$} & Subjective norms \\
\hline & & Social factors \\
\hline & & Image \\
\hline \multirow[t]{3}{*}{$\begin{array}{l}\text { Facilitation } \\
\text { conditions }\end{array}$} & \multirow{3}{*}{$\begin{array}{l}\text { Facilitating conditions are defined as the } \\
\text { degree to which an individual believes that } \\
\text { an organizational and technical } \\
\text { infrastructure exists to support the use of } \\
\text { the system. }\end{array}$} & $\begin{array}{l}\text { Perceived } \\
\text { control }\end{array}$ \\
\hline & & Facilitating conditions \\
\hline & & Compatibility \\
\hline \multirow{4}{*}{$\begin{array}{l}\text { Attitude } \\
\text { towards using } \\
\text { Technology }\end{array}$} & \multirow{4}{*}{$\begin{array}{l}\text { An individual's overall affective reaction } \\
\text { towards using a system }\end{array}$} & Attitude towards Behavior \\
\hline & & Intrinsic motivation \\
\hline & & Affect towards use \\
\hline & & Affect \\
\hline
\end{tabular}

Source: Developed by the Researcher 


\section{Extended Unified Theory of Acceptance \& Use of Technology (UTAUT2)}

UTAUT2 is an extension of the research context of UTAUT theory from the organization to the consumer by incorporating three constructs into UTAUT: hedonic motivation, price value and habit (Venkatesh et al., 2012). Venkatesh et al. (2012) carefully illustrated the context of the UTAUT2.

They stated that the consumer technology use happens in a context which is unlike that of technology use in the workplace; the consumer needs to purchase the device and also needs a service to use that technology. The only difference is that he or she needs to purchase a device to access the technology or a service to log in to use the technology. It is not only purchasing an item online, but also using an application on a mobile phone or a computer using the internet (e. g. gameplay from a mobile phone using the Internet). UTAUT2 considers the cost (internet and device charges) associated with the use of technology (use application or technology) instead of the cost of merely purchasing the item (Venkatesh et al., 2012). Actually, purchasing an item is not considered at all in this context. Further, age, gender and experience act as moderators, unlike voluntariness. In addition, there is a relationship between facilitating conditions and behavioral intention (Venkatesh et al., 2012).

Venkatesh et al. (2012) mention the target population as the current users of mobile Internet technology. Here, Venkatesh et al. (2012)'s study concerns the adoption of mobile Internet use as a technology. Hence, UTAUT2 is tested by collecting data from consumers' use of the mobile Internet technology in Hong Kong (Venkatesh et al., 2012). Furthermore, Venkatesh et al. (2012) illustrated the domain specified in UTAUT as that where mobile Internet enables people to exchange messages, pictures and e-mails, check flight schedules, book concert tickets, and enjoy games, among other uses.

Table 12: Extended Unified Theory of Acceptance and Use of Technology (UTAUT2)

\begin{tabular}{|l|l|}
\hline Variable & Definition \\
\hline $\begin{array}{l}\text { Performance } \\
\text { Expectancy }\end{array}$ & Adopted from UTAUT \\
\hline Effort Expectancy & Adopted from UTAUT \\
\hline Social Influence & Adopted from UTAUT \\
\hline $\begin{array}{l}\text { Facilitation } \\
\text { condition }\end{array}$ & Adopted from UTAUT \\
\hline Hedonic Motivation & $\begin{array}{l}\text { Define hedonic motivation as the fun or pleasure derived from using } \\
\text { a technology, and it has been shown to play an essential role in } \\
\text { determining technology acceptance and use (Brown and Venkatesh, } \\
\text { 2005). }\end{array}$ \\
\hline Price value & $\begin{array}{l}\text { Identify price value as consumers' cognitive tradeoff between the } \\
\text { perceived benefits of the applications and the monetary cost of } \\
\text { using them. (Dodds et al.,1991) }\end{array}$ \\
\hline Habit & $\begin{array}{l}\text { Habit has been defined as the extent to which people tend to } \\
\text { perform behaviors automatically because they have learnt how to } \\
\text { do them. (Limayem et al., 2007). }\end{array}$ \\
\hline
\end{tabular}

Source: Developed by the Researcher 


\section{Critical Evaluation of Technology Acceptance Models}

\section{Difference between Contexts}

Stofega and Llamas (2009) and Venkatesh et al. (2012) state that UTAUT was originally developed to determine technology acceptance by a worker in an organizational context. Technology acceptance is critical in extending UTAUT to measure another context such as consumer acceptance of technologies in which consumers are involved in a number of technology devices, money, credit card applications and services. The worker in an organization is bounded by the organizational chain of command with rules and regulations enforced by the organization, while the consumer can act on his/her own. The primary objective of a worker in an organization is to meet the organizational goals and objectives. The consumer has met his/her own goals and objectives in accepting the technology. Hence, the worker and consumer are not really similar, since they operate in two different contexts. A worker in an organization is involved in accepting a technology and using it for a job at work. However, the consumer needs to decide to accept and use a new technology to purchase goods using that technology. Both, the worker and consumer, face the same challenges in accepting a new technology, but the worker gets it for free, while the consumer needs to pay for that technology. Hence, money and cost are involved in the e-commerce context (Dodds et al., 1991; Brown \& Venkatesh, 2005; Coulter \& Coulter, 2007 and Chan et al., 2008). Venkatesh et al. (2012) stated that users are responsible for the costs in ecommerce, and being decisive can dominate consumers' adoption decisions in consumer contexts, unlike in workplace contexts.

Table 133: Comparison of Technology Acceptance Models

\begin{tabular}{|l|l|l|}
\hline Theory & Context & Concept \\
\hline TRA & Society & Any behavior \\
\hline TAM & Organization & Computer usage behavior \\
\hline E-TAM & Organization & Software usage behavior \\
\hline TAM2 & Organization & Software usage behavior \\
\hline MM & Organization & Computer usage behavior \\
\hline TPB & Society & Any behavior \\
\hline C-TAM-TPB & Organization & Software usage behavior \\
\hline MPCU & Organization & Computer usage behavior \\
\hline IDT & Society & Innovation to adopt behavior \\
\hline SCT & Society & Any behavior \\
\hline UTAUT & Organization & Technology acceptance \\
\hline UTAUT2 & Society & Mobile phone technology acceptance \\
\hline
\end{tabular}

Source: Developed by the Researcher

Consumers face an additional challenge when purchasing from a retailer whom they have not met face to face. Purchasing online poses several challenges related to trust, risk, attitude and monitory values, which are not involved in the technology acceptance in an organizational context. For workers in an organization, group decisions and superiors' decisions have an enormous impact on technology acceptance, but the consumer is free from all of that.

A prior technology acceptance research has investigated the phenomenon in organizational contexts (Venkatesh et al., 2012). TAM, E-TAM, TAM2, MM, C-TAMTPB, MPCU and UTAUT theories directly measure the technology acceptance behavior in organizational contexts or 
organizational settings. Similarly, IDT and UTAUT2 measure the new technology adoption of individuals in a social context. Naturally, when an individual uses an email application or plays a game using web technology, this is an acceptance of technology in the society. The difference between a worker in an organizational context and an individual in a society is that the former is bounded by the rules and regulations of the organization while the latter is a free agent. However, both sets of theories measure the same technology acceptance behavior. It has to be emphasized that IDT and UTAUT2 cannot measure a consumer's online purchasing behavior directly. To apply TRA, there is a need to ensure a high level of volitional control (Al-Suqri \& Al-Kharusi, 2015). A high level of volitional control implies that there are no constraints involved in the behavioral context; in other words, the behavior cannot be bounded. However, credit card availability, enough money, Internet and computer devices, ICT knowledge, infrastructure, retailer constraints, and medium characteristics are all constraints involved in the online purchasing. Hence, TRA is not strictly applicable when measuring the online purchasing concept. Likewise, it is problematic to measure the online purchasing concept by using technology acceptance theories, which are all bounded by constraints related to user acceptance of technology in an organization.

\section{Difference between the Concepts}

Sharma and Mishra (2014) have defined technology adoption as the 'stage of selecting a technology for use by an individual or an organization. Simply put, the worker or user needs to accept that introduced technology and use it within the organization or in the individual context. The context related to UTAUT2 is the acceptance of a technology by a consumer. However, that technology is accepted by the consumer in a society, not by a worker in an organization. The same technology acceptance concept plays out in two different contexts; organization and society.
E-commerce or online purchasing can be described as a transaction between two parties; it is the exchange of goods, services, or information, using the web service on the Internet as the main infrastructure to the transaction processing (Rainer \& Turban, 2002 cited in Alfina et al., 2014). It can be defined as a transaction that takes place between the retailer and the consumer. Therein, goods, services, money and information are exchanged between them. For the interaction between the parties, one party needs to accept a technology such as the web, Internet and/or other devices. So, it is clear that the concept of e-commerce is not just about accepting a technology. It involves the consumer's behavior that is related to several processes, like ordering goods, transaction processing, payment methods, customer service, logistics and after sales service.

E-commerce can also be described as the consumer's engagement in electronic exchange relationships with Web retailers (Pavlou, 2014). This implies that consumers have to face two significant challenges, not only the consumer acceptance of Internet technologies as viable means of transactions, but also the consumer recognition of Web retailers as reliable merchants (Pavlou, 2014). So, there is uncertainty, risk and trust involved in the ecommerce environment - simply put, the concept of e-commerce is associated with both the concept of purchasing behavior and the concept of technology adoption intention. However, the major challenge here is not the adoption of technology.

All the former models, TAM, E-TAM, TAM2, MM, C-TAM-TPB, MPCU, and UTAUT used the concept of technology acceptance in the context of organizational culture, while the later models, UTAUT2 and IDT, used only technology acceptance in relation to the consumer. Both types of models do not consider the concepts of purchasing behavior, such as a retailer and consumer in the midst of marketplace dynamics. Hence, all these prior models are not strictly applicable to the e-commerce context. 


\section{Difference between Processes}

The processes involved in the concept of technology acceptance and e-commerce acceptance are discussed in this section. The technology acceptance process involves introducing a new technology and implementing it in an organization. Thereafter, workshops and training sessions for employees have to be organized. However, the online purchasing typically involves several activities. In the initial stage, the consumer makes an inquiry from a retailer on aspects such as browsing or gathering information, and makes a product and price comparison. In the second stage, the consumer provides some personal information by registering himself/herself using an e-mail address and describing product preferences. The third stage is the payment stage, where all sensitive information such as credit card numbers and personal information required to complete the order is processed. Finally, the consumer needs to track the delivery until the goods are received. Accepting a new technology and accepting e-commerce are two different processes. The acceptance of e-commerce involves a larger number of variables.

\section{Conclusion}

Four main constraints are considered when evaluating the acceptability of extant models to examine e-commerce. The context in which the model has been constructed applies to the situation in which it is used. Therefore, a model has to be constructed taking into account all the constructs in the concept of consumerbased electronic commerce.

Table 14: Acceptability of Prior Models

\begin{tabular}{|c|c|c|c|c|}
\hline Theory & Context & Concept & $\begin{array}{l}\text { Number of } \\
\text { Constructs }\end{array}$ & Status \\
\hline TRA & Society & Any behavior & 2 & Accept \\
\hline TAM & $\begin{array}{l}\text { Organization } \\
\text { al }\end{array}$ & $\begin{array}{l}\text { Computer } \\
\text { behavior }\end{array}$ & 3 & Reject \\
\hline E-TAM & $\begin{array}{l}\text { Organization } \\
\text { al }\end{array}$ & Software usage behavior & 4 & Reject \\
\hline TAM2 & $\begin{array}{l}\text { Organization } \\
\text { al }\end{array}$ & Software usage behavior & 5 & Reject \\
\hline MM & $\begin{array}{l}\text { Organization } \\
\text { al }\end{array}$ & $\begin{array}{l}\text { Computer } \\
\text { behavior }\end{array}$ & 4 & Reject \\
\hline TPB & Society & Any behavior & 3 & Accept \\
\hline C-TAM-TPB & $\begin{array}{l}\text { Organization } \\
\text { al }\end{array}$ & Software usage behavior & 6 & Reject \\
\hline MPCU & $\begin{array}{l}\text { Organization } \\
\text { al }\end{array}$ & $\begin{array}{l}\text { Computer usage } \\
\text { behavior }\end{array}$ & 6 & Reject \\
\hline IDT & Society & $\begin{array}{l}\text { Innovation adoption } \\
\text { behavior }\end{array}$ & 5 & Reject \\
\hline SCT & Society & Any behavior & 4 & Accept \\
\hline UTAUT & $\begin{array}{l}\text { Organization } \\
\text { al }\end{array}$ & Technology acceptance & 6 & Reject \\
\hline UTAUT2 & Consumer & Technology acceptance & 9 & Reject \\
\hline $\begin{array}{l}\text { Proposed } \\
\text { Model }\end{array}$ & Consumer & E-commerce acceptance & 30 & Accept \\
\hline
\end{tabular}

***The number of constructs in each model varies due to merging some constructs to remove redundancy. Source: Developed by the Researcher 
TAM, E-TAM, TAM2, MM, C-TAM-TPB, MPCU and UTAUT theories are directly used to measure the technology acceptance behavior in an organizational context. However, there were differences in contexts, concepts, processes and theoretical aspects when comparing between the organizational worker and the online consumer. Hence, those theories cannot be adopted to measure the online purchasing behavior as they are. Similarly, IDT and UTAUT2 measure the new technology adoption of an individual in the consumer context. Naturally, when an individual uses an email application or plays a game by using web technology, it is a form of technology acceptance by the consumer.

The difference betrween prior technology acceptance theories and UTAUT2 and IDT is that workers in an organizational context are bounded by the rules of the organization, while the individual in a society is a free agent. However, both sets of theories measure the same technology acceptance behavior. Note that the two situations are different in concept, process and theoretical aspects, though they are similar in context. A high level of volitional control requires using TRA (Al-Suqri \& AlKharusi, 2015). A high level of volitional control implies that there are no constraints involved in the technology acceptance context, where the consumer's behavior is not bounded. However, credit card availability, enough money, Internet and computer devices, ICT knowledge, infrastructure, retailer constraints, and medium characteristics are all involved in the online purchasing. Hence, TRA is not strictly applicable when measuring the online purchasing concept. Therefore, prior technology acceptance models, as well as UTAUT2 and IDT cannot be applied to ecommerce. Hence, the current researcher proposes the development of a model, which merges a new context (consumer) and concept (e-commerce) with the maximum utilization of previous technology acceptance theoretical aspects.

\section{References}

1.Ajzen, I. (1991) 'The Theory of Planned Behavior', Organizational Behavior and
Human Decision Processes, 50, pp. 179211. doi: 10.1016/0749-5978(91)90020-T. 2. Al-Suqri, M. N. and Al-Kharusi, R. M. (2015) 'Ajzen and Fishbein's Theory of Reasoned Action (TRA) (1980)', in, pp. 188204. doi: 10.4018/978-1-4666-81569.ch012.

3. Alfina, I., Ero, J., Hidayanto, A. N. and Shihab, M. R. (2014) 'The impact of cognitive trust and e-wom on purchase intention in C2C e-commerce site', Journal of Computer Science, 10(12), pp. 25182524. doi: 10.3844/jcssp.2014.2518.2524. 4. Moore, G. C., and Benbasat, I. "Integrating Diffusion of Innovations and Theory of Reasoned Action Models to Predict Utilization of Information Technology by End-Users," in Diffusion and Adoption of Information Technology, K. Kautz and J. Pries-Hege (eds.), Chapman and Hall, London, 1996, pp. 132-146.

5. Bandura, A (1982) 'Self Efficacy Mechanism in Human Agency', The American Psychological Association, Inc., Vol. 37, No. 2, 122-147: 0003066X/82/3702-0122\$00.75

6. Bandura, A. Social Foundations of Thought and Action: A Social Cognitive Theory, Prentice Hall, Englewood Cliffs, NJ, 1986.

7. Chan A., Boulé J.B., Zakian V.A., 'Two pathways recruit telomerase to Saccharomyces cerevisiae telomeres, Research Support, N.I.H., Extramural, PLoS Genet 4(10):e1000236

8. Compeau, D., \& Higgins, C. (1995). Computer Self-Efficacy: Development of a Measure and Initial Test. MIS Quarterly, 19(2), 189-211. doi:10.2307/249688

9. Davis, F. D. (1989) 'Perceived Usefulness, Perceived Ease of Use, and User Acceptance of Information Technology', MIS Quarterly, 13(3), p. 319. doi: 10.2307/249008.

10. Davis, F. D., Bagozzi, R. P. and Warshaw, P. R. (1989) 'User Acceptance of Computer Technology: A Comparison of Two Theoretical Models', Management Science, 35(8), pp. 982-1003. doi: 10.1287/mnsc.35.8.982.

11. Davis, F., Warshaw, P. and Bagozzi, R. (1992) 'Extrinsic and Intrinsic Motivation to Use Computers in the Workplace1', Journal of Applied Social Psychology, 22(14), pp. 1111-1132. 
12. Fishbein, M., and Ajzen, I. Belief, Attitude, Intention and Behavior: An Introduction to Theory and Research, Addison-Wesley, Reading, MA, 1975.

13. Limayem, M., Hirt, S.G., and Cheung, C.M.K. (2007). "How habit limits the predictive power of intention: The case of information systems continuance," MIS Quarterly (31:4), pp. 705-737.

14. Pavlou, P. A. (2014) 'Consumer Acceptance of Electronic Commerce: Integrating Trust and Risk with the Technology Acceptance Model', International Journal of Electronic Commerce, 7(3), pp. 101-134. doi: $10.1080 / 10864415.2003 .11044275$.

15. Rogers, E. M. (1995) Diffuison of Innovations, Macmillan Publishing Co., Inc. doi: citeulike-article-id:126680.

16. Sharma, R. and Mishra, R. (2014) 'A Review of Evolution of Theories and Models of Technology Adoption', Irish Marketing Journal, 6(2), p. 44. doi: 10.9790/487X1810063748.

17. StofegaW.,and Llamas R. T., (2009) 'Worldwide mobile phone 2009-2013 forecast update' IDC document Number 217209, Framingham, MA: IDC
18. Taylor, S. and Todd, P. (1995) 'Assessing IT Usage: The Role of Prior Experience', MIS Quarterly, 19(4), pp. 561570. doi: $10.2307 / 249633$.

19. Thompson, R. L., Higgins, C. A. and Howell, J. M. (1991) 'Personal Computing: Toward a Conceptual Model of Utilization', MIS quarterly, 15(1), p. 124-143.

20.Venkatesh, V. and Davis, F. D. (2000) 'A Theoretical Extension of the Technology Acceptance Model: Four Longitudinal Field Studies', Management Science, 46(2), pp. 186-204.

doi: 10.1287/mnsc.46.2.186.11926.

21. Venkatesh, V., Morris, M. G., Davis, G. B. and Davis, F. D. (2003) 'User Acceptance of Information Technology: Toward a Unified View', MIS Quarterly, 27(3), pp. 425-478. doi: $10.2307 / 30036540$.

22. Venkatesh, V., Thong, J. Y. L. and Xu, X. (2012) 'Consumer Acceptance And Use of Information Technology: Extending The Unified Theory of Acceptance And Use Of Technology Viswanath', Forthcoming in MIS Quarterly, 36(1), pp. 157-178. doi: 10.1016/j.rser.2016.06.093. 